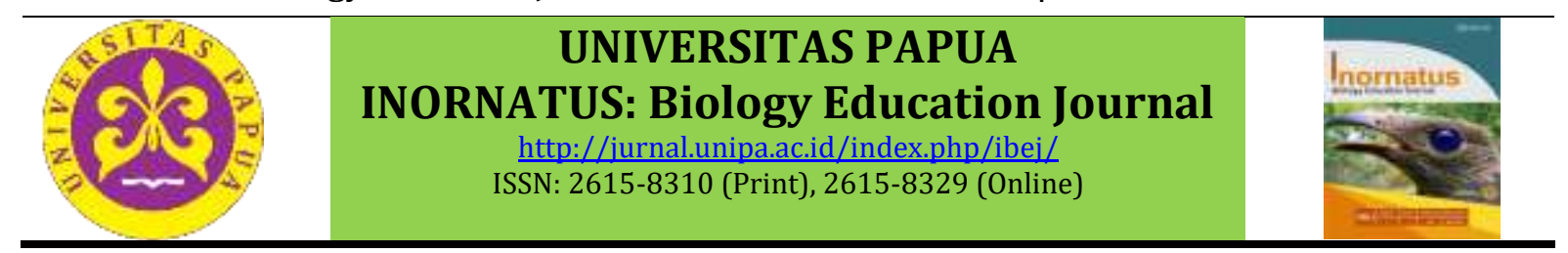

\title{
Development of Biology Interactive Learning Multimedia on Animal Tissue Topic in The Class XI IPA in SMA Yapis Manokwari
}

\section{Pengembangan Multimedia Pembelajaran Interaktif Mata Pelajaran Biologi Pokok Bahasan Jaringan Hewan Kelas XI Program IPA Di SMA Yapis Manokwari}

\author{
Wisnu Aziz Bahtiar , Jan H. Nunaki *, I. Iwan \\ Pendidikan Biologi FKIP Universitas Papua \\ *korespondensi penulis : j.nunaki@unipa.ac.id
}

\begin{abstract}
The development research aims to develop interactive multimedia-based learning media on valid, practical and effective animal tisue material. This development research refers to the ADDIE development model. Based on the data analysis obtained value of validity and media based on material expert got the value of 0,92 with valid category while in terms of media diperolch value of validty for interactive learning media 0,94 with valid category, practice media obtained from the observation aheet of instructional media implementation with a value of 91,67 with good category meanwhile for the effectiveness aspect derived from 4 assessmet of student active with a value of 98,30 where the learning media is said to be effective in learning if the activities of learners in the lesson $75 \%$ the ability of teachers to manage learning with the acquisition value of 3,28 are included in the category of moderate, test results learners with completeness of individual acquisition of 21 people with mastery mask $95,5 \%$ and quistonnaire response of learners with the acquisition of 75,76 learners respond positively to interactive media learning
\end{abstract}

keywords: Instructional media, multimedia, anactive multimedia learning, ADDIE model

\begin{abstract}
Abstrak
Penelitian pengembangan bertujuan untuk mengembangkan media pembelajaran berbasis multimedia interaktif pada materi tisue hewan yang valid, praktis dan efektif. Penelitian pengembangan ini mengacu pada model pengembangan ADDIE. Berdasarkan hasil analisis data diperoleh nilai validitas dan media berdasarkan ahli materi mendapat nilai o, 92 dengan kategori valid sedangkan dalam hal media diperolch nilai validitas untuk media pembelajaran interaktif 0,94 dengan kategori valid, media praktik diperoleh dari Observasi aheet dari penerapan media pembelajaran dengan nilai 91,67 dengan kategori baik sedangkan untuk aspek efektivitas berasal dari 4 penilaian siswa aktif dengan nilai 98,30 dimana media pembelajaran dikatakan efektif dalam pembelajaran jika aktivitas peserta didik dalam pelajaran $75 \%$ kemampuan guru untuk mengelola pembelajaran dengan nilai perolehan 3,28 termasuk dalam kategori sedang, hasil tes peserta didik dengan kelengkapan perolehan individu 21 orang dengan masker penguasaan 95,5\% dan tanggapan quistonnaire peserta didik dengan perolehan 75,76 peserta didik merespon positif terhadap pembelajaran media interaktif
\end{abstract}




\section{Pendahuluan}

Undang-undang No. 20 tahun 2003 tentang Sistem Pendidikan Nasional (Sisdiknas) dan Peraturan Pemerintah (PP) No.19 tentang standar pendidikan nasional menyatakan bahwa paradigma mengajar pada pendidikan saat ini haruslah bersifat student-centred yang menyenangkan. Undang-undang No. 20 pasal 40 ayat 2 berbunyi "guru dan tenaga kependidikan berkewajiban menciptakan suasana pendidikan yang bermakna, menyenangkan, kreatif, dinamis, dan dialogis". PP No.19 Tahun 2005 pasal 19 ayat 1 yang menekankan bahwa "proses pembelajaran pada satuan pendidikan diselenggarakan secara interaktif, inspiratif, menyenangkan, menantang, memotivasi peserta didik untuk berpartisipasi aktif, memberikan ruang gerak yang cukup bagi prakarsa, kreativitas, dan kemandirian sesuai dengan bakat, minat dan perkembangan fisik, serta psikologi peserta didik. Dengan adanya metoivasi yang baik, maka hasil belajar siswa ikut baik (Damopolii dkk, 2018).

Nisa dkk (2017) menyatakan bahwa reformasi pendidikan sedang dilakukan, dan regulasi atas perubahan kebijakan yang terkait pembangunan pendidikan nasional telah dimulai. Untuk itu, seluruh kebijakan yang terkait dengan perubahan, atau pembaruan, penyempurnaan dan pengembangan program pada semua jalur, jenjang dan jenis pendidikan harus diarahkan pada upaya untuk memberikan layanan pendidikan yang bermutu dan sesuai dengan standar pendidikan yang telah ditetapkan. Namun kenyataanya yang terjadi dilapangan proses belajar mengajar sering dihadapkan pada materi yang abstrak dan di luar pengalaman peserta didik sehari-hari, sehingga materi menjadi sulit diajarkan oleh guru dan sulit dipahami peserta didik. Visualisasi merupakan salah satu cara yang dapat dilakukan untuk mengkonkritkan atau menyatakan suatu hal yang bersifat abstrak.

Hakikat belajar biologi adalah adanya interaksi peserta didik dengan lingkungannya. Materi belajar biologi meliputi tumbuhan, hewan, monera, fungi, dan protista. Objek tersebut dikaji dari tingkat molekul sampai tingkat bioma. Pengkajian terhadap objek belajar yang tidak dapat dilihat oleh mata telanjang ataupun tidak dapat ditemukan di sekitar lingkungan belajar dapat menimbulkan kesulitan memahami konsep. Kesulitan tersebut dapat diatasi dengan menggunakan media belajar sehingga materi yang abstrak dapat divisualisasikan.

Materi Jaringan Hewan merupakan salah satu materi yang terdapat dalam pelajaran biologi. Pada tingkat sekolah, materi Jaringan Hewan diberikan di SMA Kelas XI semester gasal. Kajian utama materi Jaringan Hewan diantaranya adalah konsep jaringan, Struktur, Letak dan Fungsi jaringan pada hewan. Salah satu yang menjadi hambatan pada pembelajaran tentang Jaringan Hewan adalah membayangkan bagaimana mempelajari sesuatu yang berada dalam tubuh manusia atau hewan dan ukuranya sangat kecil dengan berbagai kompleksitas dan kerumitan yang ada di dalamnya, sehingga tidak cukup penjelasan mengenai jaringan hanya dengan memberikan konsep-konsep secara teoritis.

Objek materi Jaringan Hewan yang sebenarnya bersifat nyata tetapi menjadi abstrak bagi peserta didik apabila hanya dibelajarkan dengan metode ceramah. Salah satu kesulitan dalam menyajikan konsep Jaringan Hewan adalah bahwa konsep yang digambarkan berukuran mikroskopis. Keabstrakan ini menyebabkan peserta didik tidak dapat memahami materi struktur dan fungsi Jaringan secara utuh. Untuk mengatasi permasalahan tersebut, maka dibutuhkan suatu perubahan dalam hal media yang digunakan maupun cara penyusunan materi. Materi disusun dengan penyajian yang sedemikian rupa sehingga peserta didik dapat menentukan sendiri apa saja yang perlu dipahaminya. 
Dipergunakannya media dalam proses pembelajaran mampu meningkatkan pemahaman pada diri peserta didik sehingga lebih mandiri dan kreatif. Hal ini juga sesuai dengan pendapat Heinich dalam Nisa dkk (2017) "media merupakan salah satu alat komunikasi yang bermanfaat jika diimplementasikan dalam proses pembelajaran, media yang digunakan dalam proses pembelajaran disebut media pembelajaran". Menurut Werimon dkk (2018) dan Damopolii (2017) bahwa Media merupakan alat bantu yang digunakan guru untuk mentransfer informasi kepada siswanya.

Media merupakan alat bantu dalam kegiatan belajar mengajar. Alat bantu dapat mewakili sesuatu yang tidak dapat disampaikan guru melalui kata-kata atau kalimat. Keefektifan daya serap anak didik terhadap bahan pelajaran yang sulit dan rumit dapat terjadi dengan bantuan alat bantu. Bahkan alat bantu diakui dapat melahirkan umpan balik yang baik dari anak didik. Dengan memanfaatkan taktik alat bantu, guru dapat menimbulkan ketertarikan belajar anak didik (Nisa dkk, 2017).

Salah satu aplikasi yang dapat digunakan untuk membuat media pembelajaran yakni Autoplay Media Studio 8, yang merupakan media pembelajaran interaktif yang mampu menarik perhatian peserta didik. Autoplay Media Studio 8 merupakan aplikasi yang dapat menggabungkan baik itu tulisan, gambar, suara, animasi, video dan flash Media pembelajaran berbasis aplikasi Autoplay media studio 8 ini merupakan aplikasi yang tergolong mudah dalam penggunaannya, karena dalam pembuatan menggunakan Autoplay ini tidak serumit dengan aplikasi yang berbasis script dengan bahasa pemograman.

Tentunya dengan kemudahan aplikasi ini guru tidak hanya menggunakan saja namun dapat membuat media pembelajaran yang menarik dan sederhana dengan cara yang mudah. Autoplay merupakan aplikasi media pembelajaran yang mudah untuk digunakan baik dari segi pembuatan dan penggunaan.

Berdasarkan hasil observasi selama PPL (Praktik Pengalaman Lapangan) di SMA Yapis Manokwari ditemukan bahwa penggunaan sumber belajar masih terbatas pada media cetak seperti buku paket dan LKPD. Pemanfaatan sumber belajar lain seperti CD interaktif, audiotape, videotape, CD-ROM, atau media pembelajaran elektronik lainnya jarang digunakan. Hal ini disebabkan sumber belajar yang ada jumlahnya sangat terbatas, padahal sarana dan prasarana seperti laboratorium komputer dan LCD sudah tersedia.

Metode ceramah masih menjadi unggulan dalam menyampaikan materi biologi tanpa adanya dukungan media yang memadai. Oleh karena itu, solusi yang dirasa tepat untuk mengatasi terbatasnya media sebagai sumber belajar peserta didik pada mata pelajaran biologi, khususnya materi jaringan hewan adalah dengan mengembangkan media pembelajaran.

\section{2. $\quad$ Metode}

Penelitian pengembengan ini mengacu pada model pengembangan ADDIE. Pemilihan model ini didasarkan atas pertimbangan bahwa model ini dikembangakan secara sistematis dan berpijak pada landasan teoritis desin pembelajaran dan sangat cocok dengan karakteristik pengembangan multimedia interaktif. Menurut Rohman dan Amri (2013), Model ADDIE ini terdiri dari 5 langkah, yaitu: (a) Analisis (analyze) (b) Perancangan (design) Pengembangan (development) (c) Implementasi (implementation) (d) Evaluasi (evaluation)

\section{Prosedur Pengembangan Perangkat Pembelajaran}

a) Pendahuluan Penelitian 
Pendahuluan penelitian dilakukan dengan cara wawancara dengan guru mata pelajaran biologi, terkait kurikulum yang digunakan di sekolah, fasilitas pembelajaran, metode dan suasana kelas pada saat pembelajaran berlangsung.

b) Perencanaan Pengembangan

Perencanaan pengembangan media pembelajaran Biologi pokok bahasan Jaringan hewan di SMA Yapis manokwari menggunakan perencanaan atau model ADDIE, dan dikolaborasikan dengan model pembelajaran di kelas, ada pun tahapan dari perencanaan pengembangan tersebut yaitu:

a. Analisis (Analyze)

Analisis memiliki tahapan sebagai berikut:

i. Menganalisis kompetensi yang di tuntut kepada peserta didik, dalam hal ini kompetensi pada kurikulum, dan fasilitas yang dapat digunakan dalam pembelajaran.

ii. Analisis karakteristik peserta didik, analisis dilakukan dengan cara mewawancarai guru mata pelajaran Biologi terkait karakteristik peserta didik dalam pembelajaran dalam kelas.

iii. Analisis materi sesuai dengan kompetensi, analisis materi diawali dengan melihat kurikulum yang digunakan di sekolah.

b. Desain (Design)

Adapun tahapan dalam desain perancangan memiliki kegiatan-kegiatan sebagai berikut:

i. Merumuskan tujuan instruksional, tujuan istruksional atau tujuan pembelajaran disusun berdasarkan kurikulum yang digunakan di sekolah, dalam hal ini sekolah menggunakan kurikulum 2013.

ii. Membuat Outline konten, outline konten di rancang berdasarkan rumusan tujuan pembelajaran. Syarat outline multimedia harus dipenuhi yaitu judul multimedia, tujuan dan garis besar/isi (materi) Multimedia.

iii. Membuat Flowchart, flowchart adalah urutan dan struktur sebuah program, struktur yang digunakan adalah struktur horizontal.

iv. Mendesain tampilan, pada tahap desain tampilan kegiatan-kegiatan yang dilakukan adalah memberikan teks, grafik, menambahkan animasi. Kegiatan ini sangat penting karena dengan adanya teks, grafik dan animasi akan terlihat hidup dan menarik ketika digunakan.

c. Pengembangan (Development)

Kegiatan pngembangan adalah kegiatan menerjemahkan spesifikasi desain kedalam bentuk fisik, sehingga menghasilkan prototype produk pengembangan. Adapun kegiatan yang dilakukan yaitu:

i. Pengumpulan sumber informasi, sumber informasi seperti yang didapat melalui artikel dari internet, jurnal, dan buku.

ii. Penyatuan teks, grafik dan animasi, pada tahap ini teks, grafik dan animaisi yang telah dibuta digabungkan menjadi satu kesatuan.

iii. Menulis naskah media, naskah media yang dimaksud adalah materi pembelajaran yang akan dipelajari, dengan diperoleh dari berbagai sumber.

iv. Penyusunan instrumen evaluasi, instrumen yang disusun adalah instrumen notes yang akan digunakan untuk melihat kevalidan produk yang dihasilkan dan melihat respon peserta didik terhadap kualitas produk.

v. Validasi media pembelajaran, kegiatan validasi dilakukan oleh ahli materi dan ahli media. 


\section{d. Implementasi (Implementation)}

Tahap keempat adalah implementasi, hasil pengembangan diharapkan dalam pembelajaran untuk mengetahui kualitas pembelajaran dengan menggunakan media pembelajaran yang meliputi aspek materi pembelajaran, efisiensi, keefektifan dan teknis media pembelajaran.

\section{e. Evaluasi (Evaluation)}

Pada tahap terakhir adalah melakukan evaluasi yaitu untuk melihat apakah produk yang di kembangkan sesuai dengan yang diharapkan atau tidak. Evalusi dilakukan pada tahap pengembangan dan tahap implementasi, evaluasi yang digunakan pada penelitian ini adalah evaluasi formatif, karena jenis evaluasi ini berhubungan dengan tahapan penelitian pengembangan untuk memperbaiki produk pengembangan yang dihasilkan.

c) Validasi Perangkat Pembelajaran

a. Validasi

Produk yang telah dibuat kemudian dipriksa dan divalidasi oleh para ahli yang berpengalaman. Para ahli tersebut adalah para ahli materi dan para ahli media untuk memberikan penilaian yang berupa masukan, kritik atau sara terhadap produk yang dihasilkan. Validasi akan dilakukan terus menerus hingga produk yang dihasilkan menjadi lebih baik. Hasil validasi yang dilakukan oleh para ahli kemudian dianalisis untuk mengetahui kelemahan-kelemahan yang masih ada pada produk yang dihasilkan.

Produk yang telah melewati tahap validasi kemudian diujicoba kepada peserta didik untuk mengetahui respon peserta didik terhadapa produk yang telah dikembangkan. Selain validasi produk, proses validasi juga meliputi perangkat pembelajaran, seperti RPP dan lembar kerja peserta didik. Sedangkan untuk validasi instrumen meliputi validasi lembar keterlaksanaan media pembelajaran, lembar aktifitas peserta didik/guru, angket respon peserta didik dan tes hasil belajar. Validitas yang digunakan pada penelitian ini adalah vaiditas isi dan validitas konstruk.

\section{b. Instrumen Penelitian}

i. Lembar Validasi

Lembar validasi ini digunkan untuk memperoleh data kualitatif dari dua ahli yaitu ahli materi dan ahli media. Lembar validasi yang diberikan kepda ahli materi bertujuan untuk menilai media yang mencangkup pelajaran dan isi/materi. Sedangkan lembar validasi yang diberikan kepada ahli media adalah untuk menilai media pembelajaran yang meliputi tampilan dan pemrograman. Penilaian dalam lembar validai untuk ahli materi dan ahli media adalah menggunakan sekala likert dalam bentuk suatu pertanyaan dan memiliki 5 (lima) respon yang menunjukan tingkatan. Lima respon yang menunjukan tingkatan yaitu: sangat valid, valid, cukup valid, kurang valid dan tidak valid.

\section{ii. Angket Respon Peserta Didik}

Angket respon peserta didik digunakan untuk mengetahui respon peserta didik terhadap media berbasis multimedia ketika telah digunakan pada saat pembelajaran. Angket respon pesertta didik dalam hal ini menggunkan sekala Guttman yakni 1 apabila peserta didik melakukan kegiatan tersebut dan 0 apabila peserta didik tidak melakukan kegiatan tersebut.

iii. Lembar Observasi Kegiatan Guru Dan Peserta didik

Lembar observasi kegiatan guru dan peserta didik digunakan untuk mengetahui efektivitas media pembelajaran selama kegiatan pembelajaran berlangsung dikelas. 
iv. Lembar Keterlaksanaan Media Pembelajaran

Lembar Observasi keterlaksanaan media pembelajaran ini digunakan untuk mengetahui tingkat keefektifan media, dengan melihat apakah media dapat membantu dalam dalam proses pembelajaran atau tidak.

v. Instrumen Tes Hasil Belajar

Instrumen tes hasil belajar digunakan untuk mengetehui tingkat pemahaman peserta didik terhadap materi yang telah diajarkan sesuai tujuan yang ingin dicapai. Tes hasil belajar digunakan sebagai bahan pertimbangan untuk perbaikan media pembelajaran.

c. Teknik Analisa Data

Penelitian ini menggunakan teknik analisis data yaitu teknik analisis data deskriptif kuantitatif, dan teknik analisis data deskriptif kualitatif.

i. Teknik Analisis Data Deskriptif Kualitatif

Data kualitatif merupakan data yang menunjukkan kualitas atau mutu sesuatu yang ada, baik keadaan, proses, peristiwa/kejadian dan lainnya yang dinyatakan dalam bentuk pernyataan atau berupa kata-kata. Analisis kualitatif dilakukan dengan teknik deskriptif. Teknik ini digunakan untuk mengolah data atau masukan yang diperoleh dari ahli, guru, maupun peserta didik mengenai perangkat yang digunakan maupun media pembelajaran yang dikembangkan.

ii. Teknik analisis data deskriptif kuantitatif

a) Kevalidan

Analisis kevalidan dilakukan dengan menggunakan teknik Gregory. Langkah-langkah dalam melakukan analisis kevalidan adalah sebagai berikut (Gregory, 2000:98-99 dalam Suastika, 2013):

i. Hasil penilaian dari ahli dan guru dikelompokkan menjadi dua bagian yaitu skala (1) dan (2) dikelompokkan menjadi kurang relevan sedangkan skala (3) dan (4) dikelompokkan menjadi sangat relevan.

ii. Hasil penilaian tersebut kemudian ditabulasikan kedalam bentuk matrik tabulasi silang $(2 \times 2)$ dan memasukkan data hasil tabulasi silang kedalam rumus validasi. Rumus validasi yang digunakan adalah sebagai berikut:

$$
\text { Validasi }=\frac{D}{A+B+C+D}
$$

Keterangan:

$\mathrm{A}=$ sel yang menunjukkan pendapat kedua penilai menyatakan bahwa butir kurang relevan.

$\mathrm{B}=$ sel yang menunjukkan pendapat penilai I menyatakan bahwa butir sangat relevan sedangkan penilai II menyatakan butir kurang relevan.

$\mathrm{C}=$ sel yang menunjukkan pendapat penilai I menyatakan bahwa butir kurang relevan sedangkan penilai II menyatakan bahwa butir sangat relevan.

$\mathrm{D}=$ sel yang menyatakan pendapat kedua penilai menyatakan bahwa butir sangat relevan. 
iii. Mengkonversi hasil perhitungan kedalam kriteria validasi seperti yang disajikan dalam tabel 3.1.

Tabel 1 Kriteria Validasi

\begin{tabular}{cc}
\hline Interval Skor & Kriteria Kevalidan \\
\hline $\mathbf{0 , 8 0 - 1 , 0 0}$ & Sangat valid \\
$\mathbf{0 , 6 0}-\mathbf{0 , 7 9}$ & Valid \\
$\mathbf{0 , 4 0}-\mathbf{0 , 5 9}$ & Cukup valid \\
$\mathbf{0 , 2 0 - 0 , 3 9}$ & Kurang valid \\
$\mathbf{0 , 0 0 - 0 , 1 9}$ & Tidak valid \\
\hline
\end{tabular}

Instrumen penelitian dapat digunakan apabila nilai yang didapatkan berada dalam kriteria valid.

b) Kepraktisan

Langkah-langkah dalam melakukan analisis kepraktisan adalah sebagai berikut (Aufika, 2015;61-62)

i. Tabulasi data skor hasil observasi keterlaksanaan media pembelajaran dengan memberikan skor 1 untuk "Ya" dan 0 untuk "Tidak".

ii. Menghitung hasil persentase keterlaksanaan media pembelajaran dengan rumus:

$$
k=\frac{\text { skor tiap aspek }}{\text { skor maksimal tiap aspek }} \times 100
$$

iii. Mengkonversi hasil persentase keterlaksanaan pembelajaran $k$ menjadi nilai kualitatif berdasarkan kriteria penilaian skala 5 yang diadaptasi dari Nana Sudjana (2016:118) seperti yang disajikan dalam tabel 3.2.

Tabel 2 Kriteria keterlaksanaan media pembelajaran

\begin{tabular}{cc}
\hline Interval Skor & Kriteria Keterlaksanaan \\
\hline$k \geq 90$ & Sangat baik \\
$80 \leq k<90$ & Baik \\
$70 \leq k<80$ & Cukup \\
$60 \leq k<70$ & Kurang \\
$k<60$ & Sangat kurang \\
\hline
\end{tabular}

Media pembelajaran dikatakan praktis apabila kualifikasi tingkat kepraktisan yang didapatkan adalah baik.

c) Keefektifan

Data keefektifan diperoleh dari:

i. Lembar observasi aktivitas peserta didik

Pengamatan aktivitas peserta didik dilakukan pada dua kelompok saja untuk mewakili pengamatan terhadap peserta didik secara keseluruhan. Hal ini dilakukan untuk keefektifan dan keakuratan data oleh observer. Data hasil observasi aktivitas peserta didik selanjutnya dianalisis sebagai berikut:

(i) Menghitung frekuensi rata-rata tiap pertemuan dan dilakukan dengan cara menjumlah frekuensi aspek yang dimaksud dibagi jumlah peserta didik yang diamati.

(ii) Menghitung persentase tiap pertemuan dilakukan dengan cara membagi frekuensi rata-rata tiap pertemuan dengan jumlah frekuensi semua pertemuan tersebut dikali 100\% atau:

$$
\mathrm{P}_{\mathrm{ta}}=\frac{\Sigma^{T a}}{\Sigma^{T}} \times 100 \%
$$


Keterangan:

$\mathrm{P}_{\mathrm{ta}} \quad=$ persentase aktivitas peserta didik untuk melakukan suatu jenis aktivitas

$\sum \mathrm{Ta} \quad=$ jumlah jenis aktivitas tertentu yang dilakukan peserta didik setiap pertemuan

$\sum \mathrm{T}=$ jumlah seluruh aktivitas setiap pertemu an

Aktivitas peserta didik dikatakan efektif jika kegiatan peserta didik dalam rencana pelaksanaan pembelajaran (RPP) sebanyak 75\% dilakukan.

ii. Lembar observasi kemampuan guru mengelola pembelajaran

Data tentang kemampuan guru dalam mengelola pembelajaran dianalisis dengan menggunakan statistik deskripsi dengan skor rata-rata. Dari hasil pengamatan observer ditentukan nilai pengamatan kemampuan guru mengelola pembelajaran. Nilai yang didapatkan kemudian dikriteriakan sesuai dengan kriteria kemampuan guru mengelola pembelajaran disajikan dalam tabel 3.

Tabel 3 Kriteria kemampuan guru mengelola pembelajaran

\begin{tabular}{cc}
\hline Interval Skor & Kriteria \\
\hline $\mathrm{KG} \geq 4,5$ & Sangat tinggi \\
$3,5 \leq \mathrm{KG}<4,5$ & Tinggi \\
$2,5 \leq \mathrm{KG}<3,5$ & Sedang \\
$1,5 \leq \mathrm{KG}<2,5$ & Rendah \\
$\mathrm{KG}<1,5$ & Sangat rendah \\
\hline
\end{tabular}

(iwan, 2011)

Kemampuan guru dalam mengelola pembelajaran dikatakan efektif jika rata-rata skor minimal berada pada kriteria tinggi.

iii. Tes hasil belajar

Data hasil belajar dianalisis secara kuantitatif dengan statistik deskriptif untuk mengukur penguasaan peserta didik terhadap materi. Peserta didik dikatakan tuntas belajar secara individu apabila nilai hasil belajar yang didapatkan $\geq 65$ sesuai dengan KKM yang ditentukan oleh sekolah seperti disajikan dalam tabel 3.4. Rumus untuk menghitung ketuntasan belajar peserta didik secara individu adalah (kemetrian pendidikan dan kebudayaan, 2017;25)

$$
\text { Nilai }=\frac{\text { Total skor perolehan }}{\text { Total skor maksimal }} \times 100
$$

Tabel 4 Kriteria ketuntasan belajar individu

\begin{tabular}{cc}
\hline Interval Skor & Kriteria \\
\hline $65-100$ & Tuntas \\
$0-64$ & Tidak tuntas \\
\hline
\end{tabular}

Sumber: SMP Yapis Manokwari

Sedangkan untuk ketuntasan klasikal (KK) dikatakan tuntas apabila sebanyak 75\% peserta didik tuntas belajar (Mulyasa, 2004:19 disitasi Sopandi, 2013:46 dengan modifikasi oleh peneliti pada nilai KKM)

$$
K K=\frac{\text { Jumlah peserta didik mendapatkan } \geq 65}{\text { Jumlah siswa mengikuti tes }} \times 100
$$


Keterangan:

$\mathrm{KK}=$ ketuntasan Klasikal

Media pembelajaran dikatan efektif jika ketuntasan klasikal yang diperoleh oleh kelas mencapai standar yang ditentukan yakni $75 \%$

iv. Angket respon peserta didik

Data respon peserta didik yang diperoleh melalui angket respon peserta didik dianalisis dengan menggunakan statistik deskriptif dalam bentuk persentase. Kegiatan yang dilakukan untuk menganalisis data respon peserta didik yaitu dengan menghitung banyaknya peserta didik yang memberikan respon positif terhadap kegiatan pembelajaran yang menggunakan multimedia interaktif lalu mencocokkan hasil dengan kriteria yang ditetapkan. Persentase dari setiap respon peserta didik dihitung dengan rumus:

$$
\text { Persentase respon }=\frac{\text { jumlah respon positif setiap aspekyang muncul }}{\text { jumlah seluruhsiswa }} \times 100 \%
$$

Kriteria yang ditetapkan untuk menentukan bahwa peserta didik memiliki respon positif terhadap media pembelajaran interaktif adalah jika lebih dari 50\% peserta didik memberikan respon positif terhadap minimal 70\% dari jumlah aspek yang ditanyakan. (Nurdin, 2007 disitasi Ngatini, 20016:57). Kriteria respon peserta didik yang digunakan disajikan dalam tabel 5

Tabel 5 Kriteria Respon Peserta didik

\begin{tabular}{cc}
\hline Interval skor & Kriteria \\
\hline $3,5 \leq \mathrm{RS}$ & Sangat positif \\
$2,5 \leq \mathrm{RS}<3,5$ & Positif \\
$1,5 \leq \mathrm{RS}<2,5$ & Cukup positif \\
$0,5 \leq \mathrm{RS}<1,5$ & Tidak positif \\
$\mathrm{RS}<0,5$ & Sangat tidak positif \\
\hline
\end{tabular}

Respon peserta didik dikatakan memenuhi kriteria positif jika minimal berada pada kategori positif, dan kelas merespon positif apabila 70\% peserta didik memberikan respon positif.

\section{Hasil dan Pembahasan}

\section{Validasi Multimedia Pembelajaran Interaktif}

Ada beberapa aspek yang divalidasi pada multimedia pembelajaran interaktif yaitu, validasi dari segi isi materi pembelajaran yang terdapat dalam multimedia pembelajaran interaktif dan dari segi tampilan mulultimedia pembelajaran interaktif.

Tabel 6. Pengelompokan Hasil Penilaian Media

\begin{tabular}{ccccccccc}
\hline & \multicolumn{3}{c}{ Validator 1 } & \multicolumn{4}{c}{ Validator 2 } \\
\cline { 2 - 8 } Jenis Tes & \multicolumn{2}{c}{ SR } & KR & \multicolumn{2}{c}{ SR } & KR \\
\cline { 2 - 8 } & Skor & Skor & Skor & & Skor \\
\cline { 2 - 8 } & $\mathbf{5}$ & $\mathbf{4}$ & $\mathbf{2}$ & $\mathbf{3}$ & $\mathbf{5}$ & $\mathbf{4}$ & $\mathbf{2}$ & $\mathbf{3}$ \\
\hline Media & 6 & 12 & 0 & 0 & 5 & 12 & 0 & 1 \\
\hline
\end{tabular}

Ket: SR (Sangat Relevan), KR (Kurang Relevan) 
Tabel 7 Matriks Tabulasi Silang 2x2 Dan Kriteria Kevalidan

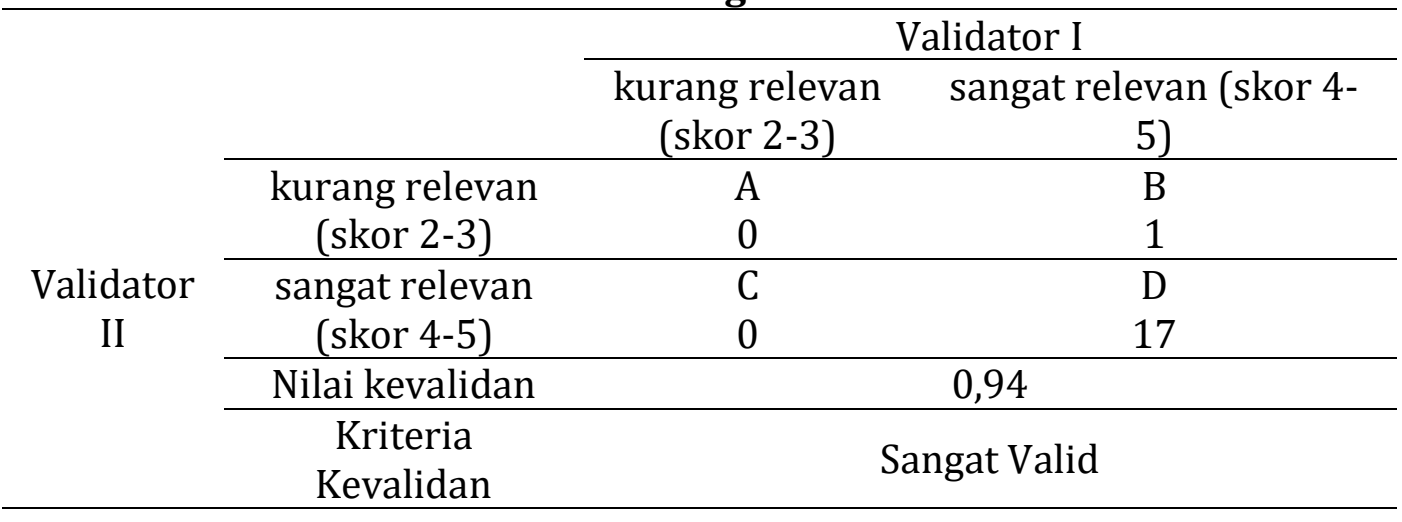

2. Kevalidan Rencana Pelaksanaan Pembelajaran (RPP)

Tabel 8 Pengelompokan Hasil Penilaian

\begin{tabular}{|c|c|c|c|c|c|c|c|c|}
\hline & \multirow{3}{*}{ Jenis Tes } & \multicolumn{4}{|c|}{ Validator 1} & \multicolumn{3}{|c|}{ Validator 2} \\
\hline & & \multicolumn{2}{|c|}{ SR } & \multicolumn{2}{|c|}{ KR } & SR & \multicolumn{2}{|c|}{ KR } \\
\hline & & 5 & 4 & 2 & 3 & 54 & 2 & 3 \\
\hline \multicolumn{2}{|r|}{ RPP } & 13 & 8 & 0 & 0 & 14 & 0 & 2 \\
\hline \multicolumn{9}{|c|}{ Ket: SR (Sangat Relevan), KR (Kurang Relevan) } \\
\hline \multicolumn{9}{|c|}{ Tabel 9 Matriks Tabulasi 2x2 Dan Kriteria Kevalidan } \\
\hline \multirow{8}{*}{ Validator II } & & & \multicolumn{6}{|c|}{ Validator I } \\
\hline & & & & $\begin{array}{l}\text { rur } \\
\text { va } \\
2\end{array}$ & $\begin{array}{l}\text { ng } \\
\text { (skor }\end{array}$ & \multicolumn{3}{|c|}{$\begin{array}{c}\text { sangat relevan (skor } \\
4-5)\end{array}$} \\
\hline & \multirow{2}{*}{\multicolumn{2}{|c|}{$\begin{array}{c}\text { kurang relevan (skor 2- } \\
\text { 3) }\end{array}$}} & \multicolumn{3}{|c|}{ A } & \multicolumn{3}{|c|}{ B } \\
\hline & & & & ( & & \multicolumn{3}{|c|}{2} \\
\hline & \multirow{2}{*}{\multicolumn{2}{|c|}{$\begin{array}{c}\text { sangat relevan (skor 4- } \\
\text { 5) }\end{array}$}} & \multicolumn{3}{|c|}{$\mathbf{C}$} & \multicolumn{3}{|c|}{ D } \\
\hline & & & & ( & & \multicolumn{3}{|c|}{19} \\
\hline & \multicolumn{2}{|l|}{ Nilai kevalidan } & \multicolumn{6}{|c|}{0,90} \\
\hline & \multicolumn{2}{|l|}{ Kriteria Kevalidan } & \multicolumn{6}{|c|}{ Sangat Valid } \\
\hline
\end{tabular}

3. Kevalidan Lembar Keterlaksanaan Media Pembelajaran

Tabel 10.Pengelompokan Hasil Penelitian

\begin{tabular}{ccccccccc}
\hline \multirow{2}{*}{ Jenis Tes } & \multicolumn{3}{c}{ Validator 1} & \multicolumn{4}{c}{ Validator II } \\
\cline { 2 - 9 } & \multicolumn{3}{c}{ SR } & \multicolumn{3}{c}{ KR } & \multicolumn{3}{c}{ SR } & \multicolumn{3}{c}{ KR } \\
& $\mathbf{5}$ & $\mathbf{4}$ & $\mathbf{2}$ & $\mathbf{3}$ & $\mathbf{5}$ & $\mathbf{4}$ & $\mathbf{2}$ & $\mathbf{3}$ \\
\hline Keterlaksanaan media pembelajaran & 1 & 7 & 0 & 0 & 2 & 6 & 0 & 0 \\
\hline
\end{tabular}

Ket: SR (Sangat Relevan), KR (Kurang Relevan)

Tabel 11 Matriks Tabulasi Silang 2x2 Dan Kriteria Kevalidan

\begin{tabular}{|c|c|c|c|}
\hline \multirow[b]{3}{*}{ Validator II } & & \multicolumn{2}{|c|}{ Validator I } \\
\hline & & $\begin{array}{c}\text { KR } \\
\text { (skor 2-3) }\end{array}$ & $\begin{array}{c}\text { SR } \\
\text { (skor 4-5) }\end{array}$ \\
\hline & $\begin{array}{c}\text { KR } \\
\text { (skor 2-3) }\end{array}$ & $\begin{array}{c}\mathbf{A} \\
0\end{array}$ & $\begin{array}{l}\text { B } \\
0\end{array}$ \\
\hline
\end{tabular}




\begin{tabular}{ccc} 
SR & C & D \\
(skor 4-5) & 0 & \multicolumn{1}{c}{8} \\
\hline Nilai kevalidan & \multicolumn{3}{c}{ Sangat Valid }
\end{tabular}

4. Kevalidan Tes Hasil Belajar

Tabel 12 Pengelompokan Hasil Belajar

\begin{tabular}{|c|c|c|c|c|c|c|c|c|c|}
\hline \multirow{3}{*}{\multicolumn{2}{|c|}{ Jenis Tes }} & \multicolumn{4}{|c|}{ Validator I } & \multicolumn{4}{|c|}{ Validator II } \\
\hline & & \multicolumn{2}{|c|}{ SR } & \multicolumn{2}{|c|}{ KR } & \multicolumn{2}{|c|}{ SR } & \multicolumn{2}{|c|}{ KR } \\
\hline & & 5 & 4 & 2 & 3 & 5 & 4 & 2 & 3 \\
\hline \multicolumn{2}{|c|}{ Tes Hasil Belajar } & 2 & 8 & 0 & 0 & 4 & 3 & 0 & 2 \\
\hline \multicolumn{10}{|c|}{ Ket: SR (Sangat Relevan), KR (Kurang Relevan) } \\
\hline \multicolumn{10}{|c|}{ Tabel 13. matriks tabulasi silang $2 \times 2$ dan kriteria kevalidan } \\
\hline \multirow{8}{*}{ Validator II } & & \multicolumn{8}{|c|}{ Validator I } \\
\hline & & \multicolumn{4}{|c|}{$\begin{array}{c}\text { KR } \\
\text { (skor 2-3) }\end{array}$} & \multicolumn{4}{|c|}{$\begin{array}{c}\text { SR } \\
\text { (skor 4-5) }\end{array}$} \\
\hline & KR & & & A & & & & $\mathbf{B}$ & \\
\hline & (skor 2-3) & & & 0 & & & & 2 & \\
\hline & SR & & & $\mathbf{C}$ & & & & D & \\
\hline & (skor 4-5) & & & 0 & & & & 8 & \\
\hline & Nilai kevalidan & \multicolumn{8}{|c|}{0,8} \\
\hline & Kriteria Kevalidan & \multicolumn{8}{|c|}{ Sangat Valid } \\
\hline
\end{tabular}

\section{Kevalidan Angket Respon Peserta didik}

Tabel 14 Pengelompokan Hasil Penilaian

\begin{tabular}{ccccccccc}
\hline \multirow{2}{*}{ Jenis Tes } & \multicolumn{4}{c}{ Validator I } & \multicolumn{4}{c}{ Validator II } \\
\cline { 2 - 9 } & \multicolumn{3}{c}{ SR } & \multicolumn{3}{c}{ KR } & \multicolumn{3}{c}{ KR } \\
& $\mathbf{5}$ & $\mathbf{4}$ & $\mathbf{2}$ & $\mathbf{3}$ & $\mathbf{5}$ & $\mathbf{4}$ & $\mathbf{2}$ & $\mathbf{3}$ \\
\hline Angket Respon Peserta didik & 1 & 10 & 0 & 0 & 2 & 9 & 0 & 0 \\
\hline
\end{tabular}

Ket: SR (sangat relevan), KR (Kurang Relevan)

Tabel 15. Matriks tabulasi silang $2 \times 2$ dan kriteria kevalidan

\begin{tabular}{cccc}
\hline & & \multicolumn{2}{c}{ Validator I } \\
\cline { 3 - 4 } & & $\begin{array}{c}\text { KR } \\
\text { (skor 2-3) }\end{array}$ & $\begin{array}{c}\text { SR } \\
\text { (skor 4-5) }\end{array}$ \\
\cline { 2 - 4 } Validator & KR & A & B \\
& II & 0 & 0 \\
\cline { 2 - 4 } & SRor 2-3) & C & D \\
\cline { 2 - 4 } & SR & 0 & 11 \\
\cline { 2 - 4 } & Nilai kevalidan & \multicolumn{3}{c}{ Sangat Valid } \\
\cline { 2 - 4 } & Kriteria Kevalidan & \multicolumn{3}{c}{} \\
\hline
\end{tabular}

\section{Analisis data keefektifan}

Data keefektifan diperoleh dari lembar observasi aktifitas peserta didik, lembar observasi kemampuan guru mengelola pembelajaran, tes hasil belajar peserta didik, dan angket respon peserta didik. 


\section{1) Lembar Observasi Aktifitas Peserta Didik}

Tabel 16. Penilaian Persentase Aktivitas Peserta Didik

\begin{tabular}{|c|c|c|c|c|}
\hline \multirow{2}{*}{ No } & \multirow{2}{*}{ Hasil Analisis Persentase Peserta didik } & \multicolumn{2}{|c|}{ Observer } & \multirow[t]{2}{*}{ Persentase (\%) } \\
\hline & & 1 & 2 & \\
\hline 1 & Memperhatikan arahan guru & 100 & 100 & 100 \\
\hline 2 & Membentuk kelompok & 100 & 100 & 100 \\
\hline 3 & $\begin{array}{l}\text { Menggunakan media pembelajaran } \\
\text { interaktif }\end{array}$ & 100 & 100 & 100 \\
\hline 4 & Mengerjakan LKPD & 100 & 100 & 100 \\
\hline 5 & Berdiskusi dengan teman satu kelompok & 90,91 & 100 & 90,91 \\
\hline 6 & $\begin{array}{l}\text { Mempresentasikan hasil diskusi di depan } \\
\text { kelas }\end{array}$ & 95,45 & 100 & 95,45 \\
\hline 7 & $\begin{array}{l}\text { Mengerjakan soal-soal latihan yang } \\
\text { berada pada media interaktif }\end{array}$ & 100 & 100 & 100 \\
\hline 8 & $\begin{array}{l}\text { Menyimpulkan hasil pembelajaran } \\
\text { bersama-sama dengan guru }\end{array}$ & 100 & 100 & 100 \\
\hline \multicolumn{2}{|c|}{ Jumlah } & & & 786,4 \\
\hline \multicolumn{2}{|c|}{ Rerata Persentase } & & & 98,30 \\
\hline
\end{tabular}

\section{2) Tes Hasil Belajar}

Tabel 17. Hasil Analisis Tes Hasil Belajar Peserta didik

\begin{tabular}{cccc}
\hline No & Kategori & Frekwensi & Persentase (\%) \\
\hline 1 & Tuntas & 21 & 95,5 \\
2 & Tidak Tuntas & 1 & 4,55 \\
\hline & Ketuntasan kelasikal & 21 & 100 \\
\hline
\end{tabular}

3) Angket Respon Peserta didik

Tabel 18. Hasil Analisis Data Respon Peserta didik

\begin{tabular}{ccc}
\hline No & Respon & Persentase (\%) \\
\hline 1 & Positif & 75,76 \\
2 & Negatif & 23,64 \\
\hline
\end{tabular}

\section{Pembahasan}

\section{Kevalidan}

Sebelum perangkat pembelajaran seperti Rencana pelaksanaan pembelajaran (RPP), LKPD, Media pembelajaran Interaktif, soal tes hasil belajar peserta didik, serta lembar-lembar penilaian, digunakan dalam penelitian, terlebih dahulu perangkat pembelajaran divalidasi oleh dosen ahli pendidikan Biologi dan guru mata pelajaran Biologi di sekolah.

Menurut susetyo dalam Wardoyo Gali Aji dkk (2017: 89) validitas suatu alat ukur dilakukan dengan mengecek secara keseluruhan oleh dua validator, valisitas kriteria dilakukan untuk memperbaiki perangkat yang dibuat, Uji coba dilakukan setelah dilakukan simulasi sebagai prediksi. Suatu alat ukur yang dapat dipercaya adalah jika 
hasil tes tidak berubah atau relatif sama apabila dilakukan pengetesan secara berulangulang. Alat ukur yang demikian dinamakan reliabel. Untuk mengetahui reliabilitas suatu media ajar digunakan indeks angka yang menunjukan media ajar yang dibuat dapat dipercaya atau diandalkan hasilnya.

Validasi perangkat pembelajaran dimaksudkan agar semua instrumen yang akan digunakan dalam penelitian agar benar-benar valid dan layak digunakan dalam penelitian. Walupun dikatakan layak oleh kedua validator tetapi ada beberapa revisi kecil yang harus dilakukan pada beberapa instrumen yaitu:

\section{a. Rencana pelaksanaan pembelajarean (RPP)}

Pada Rencana pelaksanaan pembelajaran (RPP), saran yang diberikan oleh validator dua yaitu agar dapat menambahkan tujuan, karna tujuan yang ada belum dapat melengkapi dari dua indikator yang digunkan, sedangkan untuk validator satu memberi pendapat tentang kesalahan penulisan yang dilakukan seperti kurangnya suatu huruf dalam suatu kata, huruf yang berlebihan dalam suatu kata. Sehingga RPP perlunya direvisi kembali yakni menambahkan beberapa tujuan agar dapat melengkapi indikator yang ada dan memperbaiki kesalahan-kesalahan dalam penulisan.

\section{b. Angket respon peserta didik}

Menurut validator dua ada beberapa pernyataan dalam angket respon peserta didik yang memiliki pernyataan yang sama, maka angket respon peserta didik perlu direvisi kembali untuk memperbaiki pernyataan-pernyatan yang sama ataupun yang salah.

\section{c. Media pembelajaran interaktif}

Menurut validator dua media pembelajaran interaktif yang telah dikembangkan agak sedikit berat ketika digunakan hal itu diakibatkan dari file-file yang digunkan terlalu besar. Sehingga perlu di revisi untuk ukuran file media, yaitu mengganti file yang ukuranya besar.

\section{Kepraktisan}

Dalam pengembangan media pembelajaran interaktif, data kepraktisan dibutuhkan untuk mengetahui apakah media yang telah dikembangkan memiliki sifat praktis dalam penggunaan atau pemanfaatnnya di dalam proses pembelajaraan. Sifat praktis yang dimaksud adalah media pembelajaran interaktif yang digunakan oleh guru, tidak menimbulkan kesulitan ketika digunakan di dalam preses pembelajaran, dan juga media pembelajaran interaktif tersebut tidak menimbulkan kesulitan bagi peserta didik ketika mereka inggin menggunkan media pembelajaran interaktif secara mandiri atau sendiri dirumah ataupun di tempat lain. Untuk mengetahui dan menilai kepraktisan dari medai pembelajaran interaktif yang telah dikembangkan, digunakan lembar observasi keterlaksanaan.

Lembar observasi keterlaksanaan diisi oleh kedua observer yang mengamati jalanya proses pembelajaran saat guru menggunakan media pembelajaran interaktif. Dalam penelitian ini, yang yang bertindak sebagai observer adalah seorang guru mata pelajaran Biologi dan seorang teman sejawat. Berdasarkan hasil yang diperoleh, media pembelajaran interaktif yang dikembangkan dan digunkan dalam proses pembelajaran di kelas memiliki sifat praktis atau mudah. Hal ini dilihat dari perolehan persentase lembar keterlaksanaan yakni sebesar $91,67 \%$ dan berada pada kategori baik.

Kepraktisan media ajar diperoleh dari penilaian guru dan peserta didik, kepraktisan diukur berdasarkan keterlaksanaan pembelajaran dan peserta didik yang menggunakan produk. Wardoyo Galeh aji dkk (2017: 89) 


\section{Keefektifan}

Dalam suatu pembelajaran dengan menggunakan media pembelajaran lebih baik karena membantu peserta didik memahami materi dengan gambaran yang nyata bukan konsep atau tulisan-tulisan. Maka sebab itu dibutuhkan sebuah media yang sangat berpengaruh dalam proses pembelajaran, dan seberapa besar pengaruh suatu media dapat memahamkan peserta didik, itulah yang menjadi tolak ukur keefektifan suatu media.

Efektifitas suatu produk pengembangan dinilai dari 4 hal, yaitu. 1) ketuntasan hasil belajar peserta didik, 2) Aktifitas peserta didik dan guru menunjukan kategori baik, 3) Kemampuan guru mengelola pembelajaran baik dan 4) Respon peserta didik serta guru positif. Wardoyo Galeh Aji dkk (2017: 90).

Untuk menilai keefekitifan dari media pembelajaran interaksi, ada beberapa faktor yang menjadi penilaian.

\section{a. Aktivitas Peserta Didik}

Untuk mengetahui keefektifan media pembelajaran interaktif yaitu dapat dinilai dari aktivitas peserta didik selama mengikuti proses pembelajaran ketika menggunakan media pembelajaran interaktif. Hubungan antara aktivitas pesereta didik dengan media pembelajaran interaktif adalah ketika peserta didik berperan aktif dalam menggunkan media pembelajaran interaktif, menimbulkan rasa ingin tahu dan ketertarikan terhadap media pembelajaran.

Berdasarkan hasil analisis data yang dilakukan, diperoleh nilai presentase aktivitas peserta didik sebesar $98,30 \%$ sehingga dapat disimpulkan bahwa media pembelajaran interaktif yang telah dikembangkan dan digunakan dalam proses pembelajaran bersifat efektif dan memberikan dampak yang positif.

Hal ini sejalan dengan pendapat Maisyarah (2015: 126) aktifitas peserta didik adalah keterlibatan peserta didik dalam bentuk sikap, pikiran, perhatian dan aktivitas dalam kegiatan pembelajaran guna menunjang keberhasilan proses belajar-mengajar dan memperoleh manfaat dari kegiatan tersebut.

\section{b. Kemampuan guru mengelola pembelajaran}

Kemampuan guru dalam pembelajaran dapat memberikan penilaian untuk melihat keefektifan media pembelajaran interaktif yang dikembangkan. Media pembelajaran interaktif dikatakan efektif jika penilaian kemampuan guru mengelola pembelajaran melebihi rata-rata skor minimal berada pada kategori tinggi.

Berdasarkan analisi data kemampuan guru mengelola pembelajaran, hasil yang diperoleh untuk setiap aspek yaitu kegiatan awal, kegiatan inti dan kegiatan penutup hanya berada pada kategori sedangaan sehingga dapat ditarik kesimpulan bahwa media pembelajaran interktif yang dikembangkan belum sepenuhnya efektif ketika digunakan dalam proses pembelajaran jika dilihat dari aspek kemampuan guru mengelola pembelajaran. Pada kegiatan awal ada dimana observer I dan observer II memberikan 2 poin, yaitu pada aktifitas menginformasikan SK, KD, indikator dan tujuan pembelajaran hal itu disebabkan, peneliti hanya menuliskan tujuan pembelajaran di papan tulis sedangkan untuk SK, KD dan Indikator hanya dibacakan saja ketika dalam proses pembelajaran, dan untuk katifitas yang lainya kedua observer memberikan 3 sampai dengan 4 poin.

Pada kegiatan inti didapatkan kategori setiap aspek yang dikatakan sedang, hal ini disebabkan karna kurang maksimalnya peneliti dalam melaksanakan setiap aktifitas pembelajaran, sehingga dari kedua observer memberikan poin antara 3 sampai 4, dari 
kedua poin yang diberikan dikatakan termasuk tinggi tetapi kurang maksimalnya peneliti dalam melaksanakan aktifisa sehingga mendapatkan kategori sedang, Seperti aktifitas mengarahkan peserta didik membentuk kelompok kecil pada implementasinya peneliti hanya mengarahkan peserta didik untuk membentuk kelompok kecil sehingga observer I memberikan 3 poin.

Pada kegiatan akhir aktifitas menyimpulkan hasil pembelajaran bersama peserta didik, peneliti yang bertindak sebagai guru sudah melakukan hal tersebut sudah sesuai dengan RPP yang disusun namun peneliti hanya mengambil poin-poin penting yang relevan pada materi.

\section{c. Tes hasil belajar}

Media pembelajaran iteraktif dikatakan efektif jika hasil belajar yang diperoleh oleh peserta didik secara individu adalah $\geq 65$ sesuai dengan kriteria ketuntasan minimum (KKM) yang di tentukan oleh pohak sekolah, dan secara kelasikal adalah sebesar 75\% yang telah ditentukan oleh kementrian pendidikan.

Berdasarkan hasil analisis Tes hasil belajar, didapati 21 peserta didik dinyatakan tuntas dengan perolehan nilai 100 (3 orang), nilai 90 sebanyak (5 orang), nilai 80 sebanyak ( 4 orang), dan nilai 70 sebanyak ( 9 orang), dan untuk peserta didik yang tidak tuntas yaitu sebanyak 1 orang dengan nilai 50. Maka diperoleh ketuntasan kelasikal dari keseluruhan adalah 95,5\% maka dapat ditarik kesimpulan bahwa media pembelajaran interaktif yang dikembangkan dan digunakan dalam pembelajaran dinyatakan efektif terhadap hasil belajar peserta didik. Hal ini sesuai dengan pendapat Purnomo joni dkk dalam jurnalnya (2014: 140) Penggunaan media yang tepat merupakan suatu alternatif untuk mengatasi rendahnya hasil belajar peserta didik, khususnya pada mata pelajaran Ilmu Pengetahuan Alam. Menurut Iwan dkk (2018) media pembelajaran yang dikembangkan membuat hasil belajar mencapai standar kalsikal. Penggunakan media pembelajaran yang tepat dalam mengajar, diharapkan mampu meningkatkan hasil belajar peserta didik. Keberhasilan pendidikan salah satunya ditunjukkan dengan semakin meningkatnya hasil belajar peserta didik. Faktor yang mempengaruhi tinggi rendahnya hasil belajar peserta didik antara lain adalah media yang digunakan dalam pembelajaran.

\section{d. Angket respon Peserta Didik}

Keefektifan media pembelajaran interaktif juga dilihat dari respon peserta didik setelah menggunkan media pembelajaran interaktif dalam pembelajaran. Respon yang diberikan terhadap media pembelajatran interaktif dengan 22 peserta didik diperoleh hasil $75,76 \%$ dan dapat disimpulkan media interaktif memiliki keefektifan baik dalam proses pembelajaran. Hal ini dilihat dari jumlah respon positif yang diberikan oleh peserta didik setelah belajar dengan menggunkan media pembelajaran interaktif, kriteria yang di tetapkan untuk menentukan bahwa peserta didik memiliki respon positif terhadap media pembelajaran interaktif adalah jika lebih dari $50 \%$ peserta didik memberikan respon positif terhadap minimal 70\% dari jumlah aspek yang ditanyakan

\section{Simpulan}

Bedasarkan penelitian dan pengembangan yang dilakukan, maka dapat ditarik kesimpulan sebagai berikut. Dalam pengembangan multimedia pembelajaran interaktif ini menggunkan model ADDIE (Analyze, Design, Development, Implementation, Evaliation), untuk mengetahui media pembelajaran interaktif ini layak digunkan. Berdasarkan data temuan sebagai berikut:

1. Kevalidan 
Kevalidan media pembelajaran interaktif ditentukan 2 aspek yaitu kevalidan dari segi materi dan kevalidan dari segi media. Kevalidan dari segi materi memperoleh nilai 0,92 yang dikategorikan "Sangat Valid". Sementara dari segi media memperoleh nilai 0,94 yang dikategorikan "Sangat Valid".

2. Kepraktisan

Kepraktisan suatu media pembelajaran dikatan praktis apabila kualifikasi tingkat kepraktisan yang didapat berada pada kriteria baik. Berdasarkan analisis data diperoleh nilai kepraktisan dari media pembelajaran interaktif adalah 91,67 dan berada pada kategori "sangat baik".

3. Keefektifan

Untuk melihat keefektifan media maka data yang dianalisis dari 4 sumber yakni:

a. Aktivitas peserta didik

Nilai yang diperolah dari aktivitas peserta didik adalah 98,30\%. Dan sebuah media pembelajarean dikatakan efektif jika aktivitas peserta didik dalam rencana pelaksanaan pembelajaran (RPP) terlaksana sebesar 75\%.

b. Kemampuan guru mengelola pembelajaran

Untuk nilai kemampuan guru mengelola pembelajaran adalah 3,28 yang berada pada kategori "sedang"

c. Tes hasil belajar peserta didik

Nilai dari tes hasil belajar peserta didik terhadap media pembelajaran interaktif secara klasikal adalah 95,5\% sebuah media dikatan mencapai ketuntasan klasikal apabila melebihi dari 75\% dari kelas.

d. Angket respon peserta didik

Nilai yang diperoleh dari respon peserta didik adalah 75,76\% dan kriteria yang di tetapkan untuk menentukan bahwa peserta didik memiliki respon positif terhadap media pembelajaran interaktif adalah jika lebih dari 50\% peserta didik memberikan respon positif terhadap minimal 70\% dari jumlah aspek yang ditanyakan.

\section{Referensi}

Damopolii, I. (2017). Pengaruh Model Pembelajaran Kooperatif Tipe STAD Berbantuan Media Pembelajaran Komik IPA Terpadu terhadap Peningkatan Hasil Belajar Siswa. Prosiding Simposium Nasional Universitas Negeri Makassar.

Damopolii, I., Lefaan, P. T., \& Manga, M. (2018). Hubungan Motivasi Belajar dengan Hasil Belajar Biologi Siswa Di SMP 21 Rendani Manokwari. In Prosiding Seminar Nasional Pendidikan Biologi (Vol. 1, No. 1, pp. 427-430).

Iwan. (2011). Pengembangan Perangkat Pembelajaran Materi Keanekaragaman Hayati Berorientasi Problem Based Learning Unuk Siswa Kelas 10 SMA. Dinamika Jurnal Matematika dan Ilmu Pengetahuan Alam Volume 02 No.2 hal 91-104. FMIPA. Universitas Cokroaminoto Palopo.

Iwan, I., Saputro, P. A., \& Nunaki, J. H. (2018, November). Pengembangan Media Pembelajaran Berbasis Visual (Komik IPA Terpadu) Pada Materi Fotosintesis Untuk Siswa Kelas VIII SMP Negeri 1 Manokwari. In Seminar Nasional Biologi dan Pembelajarannya, Universitas Negeri Makassar.

Kemendikbud. (2014). Peraturan Menteri Pendidikan dan Kebudayaan nomor 65 tahun 2013 tentang Standar Proses Pendidikan Dasar dan Menengah.

Maisyarah "Meningkatkan Hasil Belajar Dan Aktivitas Peserta didik Melalui Model Pembelajaran Kooperatif Tipe NHT" Jurnal, pendidikan matematika, 
Nisa, K., Mustika Wati dan Andi I Mahardika,. (2017). "Pengembngan Media Pembelajaran Berbantuan Aplikasi Autoplay Media Studio Pada Pokok Bahasan Fluida Dinamis Di SMA". Jurnal, Ilmiah Pendidikan Fisika Vol 1(1) hal 39-42.

Peraturan Menteri Pendidikan dan Kebudayaan nomor 104 tahun 2014 tentang Penilaian Hasil Belajar Oleh Pendidik Pada Pendidikan Dasar dan Menengah .

Purwono, J., Yutmini, S \& Anita,S. (2014). Penggunaan media audio-visual pada mata pelajaran ilmu pengetahuan alam di Sekolah Menengah Pertama Negeri 1 Pacitan. Jurnal Teknologi Pendidikan dan Pembelajaran, 2(2).

Sudjana, Nana dan Rinai, Ahmad. Media Pembelajaran. (2013). Bandung: Sinar Baru Algesindo.

Sumintomo, B dan Widhiarso, W. (2015). Aplikasi Model Rasch Model Untuk Peneitian Ilmu-ilmu Sosial. Cimahi: Trim Komunikata Publishing House.

Undang-undang No. 20 tahun 2003 tentang Sistem Pendidikan Nasional (Sisdiknas)

Wardoyo Galeh Aji, Syubhan An'nur dan Abdul Salam M.(2017) Pengembangan Media Ajar Multimedia Audio Visual Pada Pokok Bahasan Tekanan Di Smp" Jurnal, ilmiah pendidikan fisika, Vol 1(2) hal 89.

Werimon, S., Damopolii, I., \& Nunaki, J. H. (2017). Pengaruh Model Pembelajaran STAD Dipadu Media Pembelajaran Komik Materi Sistem Pencernaan Manusia terhadap Hasil Belajar Siswa. Jurnal Eksakta Pendidikan (JEP), 1(2), 33-40. 